Article

\title{
An Integrated Framework for Assessment of Hybrid Water Supply Systems
}

\author{
Mukta Sapkota ${ }^{1, *}$, Meenakshi Arora ${ }^{1}$, Hector Malano ${ }^{1}$, Magnus Moglia ${ }^{2}$, Ashok Sharma ${ }^{3}$, \\ Biju George ${ }^{4}$ and Francis Pamminger ${ }^{5}$
}

Received: 22 September 2015; Accepted: 17 December 2015; Published: 24 December 2015

Academic Editors: Ashantha Goonetilleke and Meththika Vithanage

1 Department of Infrastructure Engineering, Melbourne School of Engineering, University of Melbourne, Melbourne, VIC 3010, Australia; marora@unimelb.edu.au (M.A.); h.malano@unimelb.edu.au (H.M.)

2 Commonwealth Scientific and Industrial Research Organization (CSIRO), Land and Water, Clayton South, VIC 3169, Australia; Magnus.Moglia@csiro.au

3 Institute of Sustainability and Innovation, Victoria University, Melbourne, VIC 3030, Australia; Ashok.Sharma@vu.edu.au

4 International Centre for Agricultural Research in the Dry Areas, P.O. Box 2416, Cairo, Egypt; B.George@cgiar.org

5 Yarra Valley Water, Mitcham, VIC 3132, Australia; francis.pamminger@yvw.com.au

* Correspondence: msapkota@student.unimelb.edu.au; Tel.: +61-383-449-841

$+\quad$ Based on "Sapkota, M.; Arora, M.; Malano, H.; George, B.; Nawarathna, B.; Sharma, A.; Moglia, M. Development of a framework to evaluate the hybrid water supply systems. In Proceedings of the 20th International Congress on Modelling and Simulation, Adelaide, Australia, 1-6 December 2013".

\begin{abstract}
Urban water managers around the world are adopting decentralized water supply systems, often in combination with centralized systems. While increasing demand for water arising from population growth is one of the primary reasons for this increased adoption of alternative technologies, factors such as climate change, increased frequency of extreme weather events and rapid urbanization also contribute to an increased rate of adoption of these technologies. This combination of centralized-decentralized water systems approach is referred to as "hybrid water supply systems" and is based on the premise that the provision of alternative water sources at local scales can both extend the capacity of existing centralized water supply infrastructures, and improve resilience to variable climatic conditions. It is important to understand, however, that decentralized water production and reuse may change the flow and composition of wastewater and stormwater, thereby potentially also having negative impacts on its effectiveness and performance. This paper describes a framework to assess the interactions between decentralized water supply systems and existing centralized water servicing approaches using several analytical tools, including water balance modelling, contaminant balance modelling and multi-criteria decision analysis. The framework enables the evaluation of impacts due to change in quantity and quality of wastewater and stormwater on the existing centralized system arising from the implementation of hybrid water supply systems. The framework consists of two parts: (1) Physical system analysis for various potential scenarios and (2) Ranking of Scenarios. This paper includes the demonstration of the first part of the framework for an area of Melbourne, Australia by comparing centralized water supply scenario with a combination of centralized water supply and reuse of treated waste water supply scenario.
\end{abstract}

Keywords: hybrid water supply systems; urban water cycle; evaluation framework; water balance; water reuse and recycling; resilience 


\section{Introduction}

In most cities around the world, water services systems are mainly centralized. This is partly due to historical reasons, and in part due to the maturity of the technology and the opportunities for economics of scale. However, the lifespan and the planning horizon of central water infrastructures can be up to 100 years making the prediction of climate change, water availability, population growth as well as shrinkage and land use changes uncertain [1]. For instance, in some cities there are concerns about over-reliance on centralized systems in terms of their future sustainability for meeting a range of social, economic and environmental goals as well as for meeting the water demand because of the increasing growth and concentration of population in urban centers [2-4]. In some cities with shrinking populations as in Eastern Germany [5,6] and Japan [7] there are concerns about low flows in sewer pipe causing reduced critical traction forces causing sewer blockages [8] and ageing of water supply systems [1]. Centralized systems can also be vulnerable to occurrences of periodic droughts and the projected impacts of climate change [9]. Therefore, the case has been frequently made to augment the existing supply systems by integration of traditional and non-traditional supply sources [10]. This type of integration helps both in cases of increasing and decreasing population by making centralized organized water infrastructure more flexible and adaptable [1]. In the last 20 years, many alternative (non-traditional) water supply options like rainwater, stormwater and recycled water have emerged. The combination of such decentralized water supply options with centralized system which is defined as hybrid water supply systems by Sapkota, et al. [4], have displayed potential to meet the increasing water demand [11,12]. It is argued that this type of hybrid approach can thus offer flexible solutions, wherever certain thresholds of population density are exceeded $[13,14]$. These approaches help reduce the volume of water imported to cities, and in some configurations can also reduce the volumes of wastewater and stormwater discharged into the environment [15]. On the other hand, the use of these systems may have some detrimental impacts on the centralized water infrastructure, particularly on the sewage network and stormwater drains. The use of decentralized water supply systems changes both the wastewater and stormwater flow regimes and contaminants' composition [16-18]. For instance, as water saving and recycling are encouraged through grey water reuse, dual piping systems, and sewer mining, the quantity of wastewater may decrease leading to an increase in its concentration of contaminants [19]. High-concentration wastewater has been known to cause sewer problems such as sewer blockage, odor and corrosion [20]. Thus, to ensure the smooth and effective implementation of hybrid water supply systems, it is necessary to evaluate their impacts on the existing wastewater and stormwater system. Such an evaluation requires a comprehensive methodology to enable the evaluation of various subsystems and their interactions to contribute to the overall performance of hybrid systems $[4,21]$.

In most previous studies, integrated assessment of supply options has been carried out using narrow and opposing options (an either/or approach). Assessing one water supply alternative against another for a number of alternative systems has typically excluded hybrid options for partial contributions from multiple alternatives together [22]. For example Cook, et al. [23] analyzed seven alternatives and Abrishamchi, et al. [24] analyzed eight systems, however, these methodologies exclude options of combined systems and their potential benefits. In fact, until now the perceived benefits of combined centralized and decentralized approaches has only been discussed predominantly on a theoretical and ideological basis $[2,25,26]$. There is still a question of whether a mixture of a decentralized and centralized approach can combine the benefits of both systems. To answer this question of finding appropriate balance of centralized and decentralized servicing options for urban water management, we must rely on a robust understanding based on structured modelling approaches and reliable data.

At present, there is very scant literature that present assessment frameworks $[14,21,22,27]$ and empirically based evidence [28-30] leading to an objective assessment of these hybrid systems. With few exceptions, none of the previously published methodologies evaluate the impacts of hybrid 
systems in terms of the interaction between centralized and decentralized infrastructures. Some of the existing frameworks evaluate the environmental impacts of hybrid systems, however, they do not evaluate the impacts arising from the implementation of hybrid systems on the quantity and quality of wastewater and stormwater on the existing centralized systems [31]. Hence there is a need of comprehensive methodology for assessing conjointly the full range of technological alternatives available. The closest methodology for assessing the introduction of hybrid water system to date is presented by Sapkota, et al. [21]. However, this is a basic theoretical methodology that requires further empirical study to validate it via a case study application. This framework is described in this study together with an expanded description of the evaluation of hybrid water supply systems and some modifications of the methodology. This study demonstrates the systematic implementation of a subset of this framework focused on the physical aspect of the system. The analysis is based on analytical approaches to assist in understanding the interaction between centralized and decentralized systems.

\section{Conceptual Framework}

\subsection{Urban Water Cycle}

Figure 1 presents the stock-and-flow representation of a hybrid water supply system. It shows the main components of the water cycle, pathways and alternative supply options considered in this study. Demand is mainly governed by changes in population and variability in climate. To meet this demand, water can be supplied on a fit-for-purpose basis from various decentralized options (greywater, wastewater, stormwater and roof water) along with centralized supply. Unused wastewater and greywater flows to the receiving waters via a wastewater treatment plants while excess roof and grounds runoff flows to the receiving waters. In this model, water supply, wastewater and stormwater are considered within a single integrated framework to highlight their interactions. In addition, a broad range of non-conventional water supply technologies such as rainwater tanks, stormwater harvesting, and greywater reuse are considered as part of the system to analyze their impacts on the urban water cycle components. Because of the interconnectedness of the hybrid system, changes in one component of the system can have impacts on other components. The framework also considers the flow of contaminants throughout the urban area.

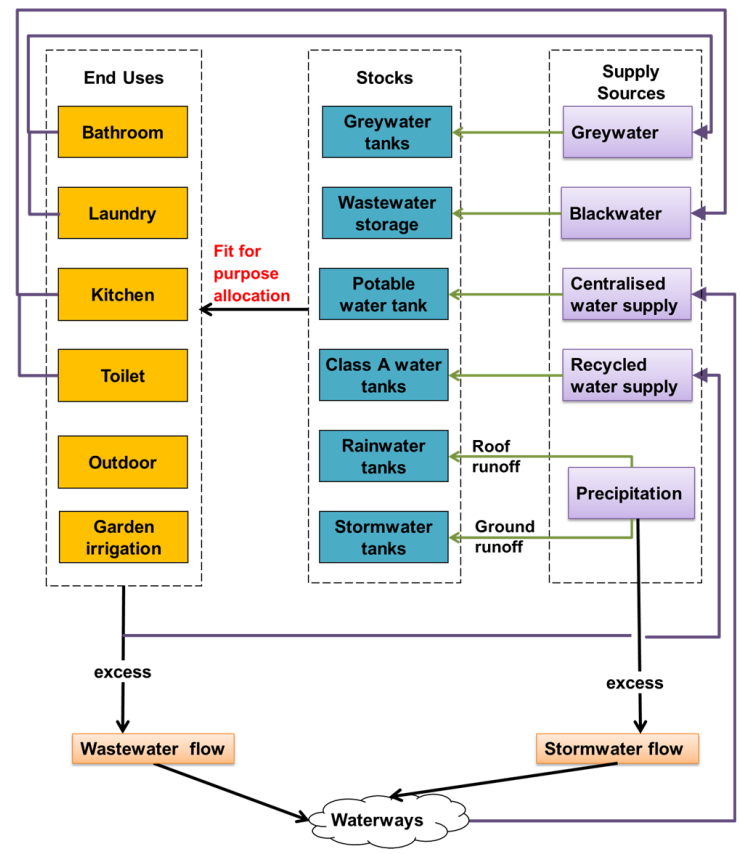

Figure 1. Stock-and-flow diagram of hybrid WSS (Water Supply System). 


\subsection{System Boundary}

Both centralised and decentralised water supply systems are considered in this study. Centralised techniques are referred to here as those applications that favour city-wide solutions, including wide-area distribution networks, large-scale water storage facilities and the development of large scale resources.

Decentralised options are defined as those being applicable at development or individual household level [9]. For the purpose of modelling, a range of sub-systems have been considered for the study: water use in residential, industrial, commercial and public areas; central water supply; urban waterways and stormwater; sewerage and wastewater treatment; and provision of alternative water sources at different scales (development, neighbourhood or allotment). The allotment/household scale herein represents a building and associated indoor and outdoor usages as well as paved and pervious areas such as pathways, driveways and gardens. The neighbourhood comprises a number of identical unit blocks as well as roads and public open space. The development/subdivision scale represents the grouping of one or more neighbourhoods that may or may not have the same land use or water servicing approach. Rainwater tanks and grey water recycling are considered at household level while stormwater harvesting and recycled wastewater are assumed to be implemented at development scale. However, rainwater usage can also be considered at development scale through the use of communal rainwater tanks [32].

\subsection{Variables}

Water flow rates, volumes and contaminants are considered in the analysis and the specific variables included in the study are water (potable water, stormwater, rainwater, greywater and wastewater) flow rates and volumes along with contaminant loads (Total Nitrogen, Total Phosphorous, Total Suspended Solids, BOD and COD). TSS, TP, TN, BOD and COD are selected to represent the contaminant loads as they are most significant measures of pollution in both runoff and wastewater [33]. Flow rates are important to assess the infrastructure capacity such as the maximum flow that water, stormwater and sewage pipes can handle. Volume is important in terms of designing water supply reservoirs, and water and wastewater treatment plant capacity.

\section{Framework to Evaluate Hybrid Water Supply Systems}

In this study we adopted a generalized framework (Figure 2) from Sapkota, et al. [21] that considers the varying nature of urban developments and forms. The framework is supported by several models and tools including water balance modelling, contaminant balance modelling, multi-criteria decision analysis (MCDA), and future change analysis. The framework has been divided into two parts: the analysis of the physical system and the ranking method. In this study, the physical system analysis is applied to a case study for the purpose of illustration consisting of two typical scenarios. A ranking methodology is proposed without an actual application which would require a larger set of scenarios.

\subsection{Physical System Analysis}

\subsubsection{Understanding the Local Conditions and Current System Capacity}

This component of the framework explores the local conditions such as local climate, geology, development pattern, future population projection and water demand, water resource availability, environmental flow requirement and wastewater and stormwater disposal limits, and system capacity quantities such as capacity of the water supply, sewage and stormwater drainage networks; water, stormwater and wastewater treatment plants. This task involves reviewing of relevant literature including reports from government authorities, policy and guidelines. An essential part of this step is to define the system boundary. Physical boundaries are selected to encompass the area 
of interest (urbanized area at development scale) and also include elements such as centralized water supply, discharge points, treatment plants and receiving waters.

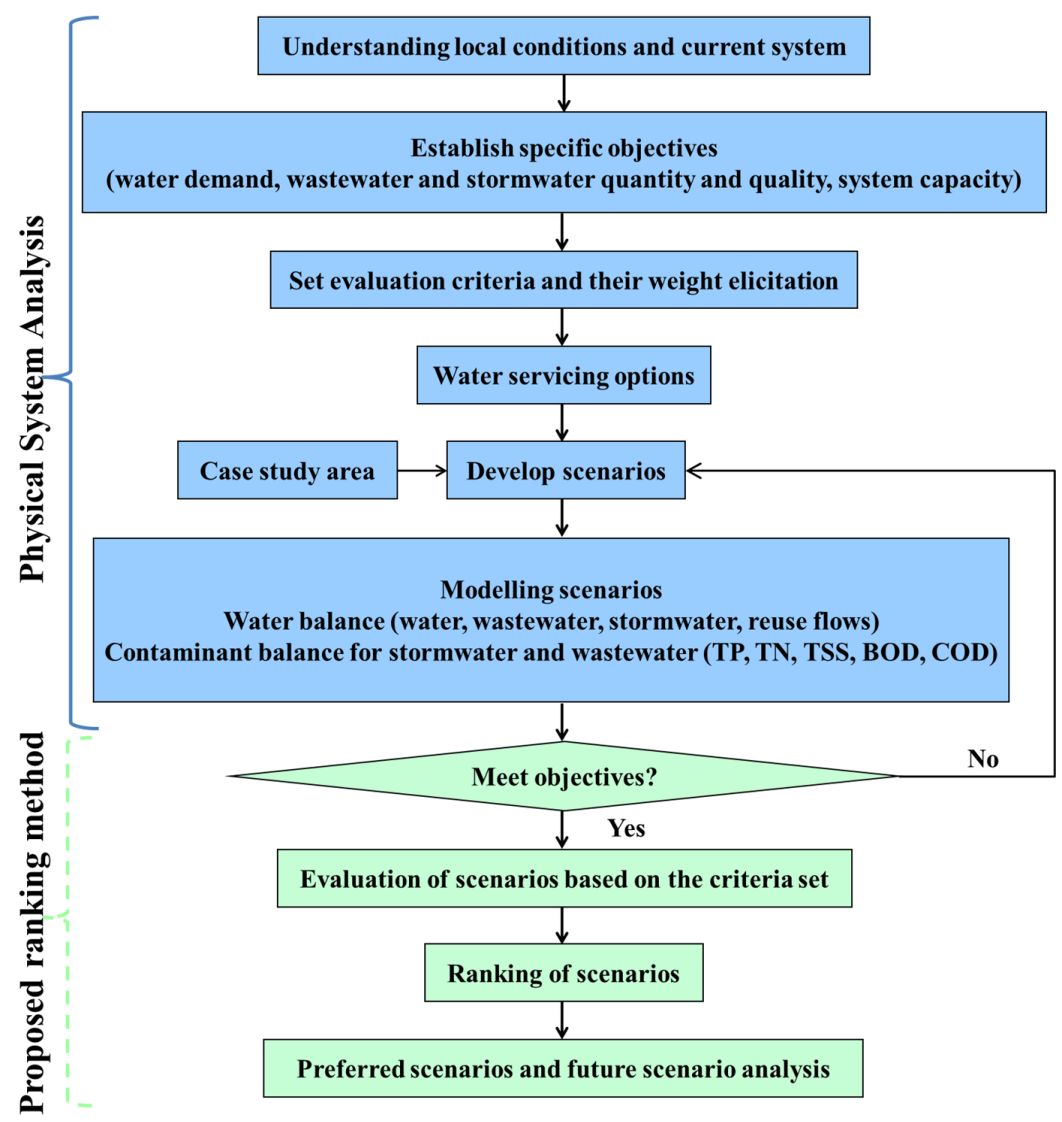

Figure 2. Framework to evaluate hybrid WSS.

\subsubsection{Establishing Specific Objectives}

Specific objectives must be set to meet water supply and demand, quantity and quality of wastewater and stormwater discharge and system capacity. These characteristics are site specific and are based on the local information and systems capacity, present water demand profile, current water supply, sewage and drainage profiles, recycled water use profile and future water demand profile and rainfall pattern.

\subsubsection{Setting the Evaluation Criteria and Their Weight Elicitation}

The study presented herein considers mainly a set of quantitative criteria that reflects the main objective of the study which is to assess the impact of decentralized systems on existing centralized infrastructures. These criteria were set in consultation with Victorian water utilities through series of workshops and personal interviews. The assessment criteria are set keeping in mind that the study is confined to the physical aspects of the system. The criteria set for the evaluation of the performance of hybrid water supply systems include:

1. Reduction in potable water demand from centralized WSS

2. Reduction in wastewater discharges both flow rate and volumes

3. Reduction in contaminant loads of wastewater flow

4. Reduction in stormwater flows both intensity and volumes

5. Reduction contaminant loads from stormwater to receiving water

6. Improvement of supply reliability of fit for purpose water 
The multi-criteria decision analysis (MCDA) in this framework requires the definition of weights. The elicitation of meaningful weights for these criteria is very important to reflect their relative importance. For this purpose, a questionnaire survey has been conducted among water professionals from local water utilities, research organizations, universities, consultancies and water associations to determine the factors that need to be considered in the evaluation criteria and the relative importance (weight) of each criterion. The survey results from 37 respondents provided almost similar weights to each criterion varying between 0.18 and 0.15 , indicating that all criteria have similar importance. Moreover, all respondents believe that none of the criteria are unimportant which demonstrates that the criteria used in the study are robust. It is widely acknowledged that the assessment of criteria weighting is a crucial step in multi-criteria decision analysis [34]. While providing these weights for MCDA, the study framework does recognize the importance of conducting a sensitivity analysis to examine the relative impacts on outputs of possible variations in weighting. However, this component is not demonstrated in this paper as the MCDA analysis is not incorporated in the case study application.

\subsubsection{Water Supply Servicing Options}

Identifying the feasible water supply options at the selected site is an important step. Options can vary based on allotment, neighborhood or development scale and availability of alternate sources. Examples of various alternative water supply options based on a fit for purpose are greywater collection and reuse, rainwater harvesting and reuse, stormwater harvesting and reuse, and sewer mining.

\subsubsection{Developing Scenarios}

In this stage, various hybrid (combination of centralized and different decentralized) water supply scenarios are developed in consultation with the water utilities that involve combinations of recycled water via third pipe, treated greywater, rainwater tanks and stormwater tanks. These are based on the combination of the selected water supply servicing options, infrastructure provision and chosen technologies. These scenarios are developed based on the current local/state Government policy and compliance with existing water legislation. For example, a hybrid water supply scenario may include potable water supply from centralized water supply system for kitchen, bath and laundry, while non-potable supply can be sourced from greywater reuse for toilet flushing and garden irrigation.

\subsubsection{Analysis of Scenarios}

A water balance analysis provides the volume and flow rate of potable water, stormwater and wastewater along with flow quantities of alternative resources based on defined end uses and size of storages for rain tanks, grey water, wastewater and stormwater reuse. There are various models available for water balance analysis such as Aquacycle [35], Hydro Planner [36], Krakatoa [37], UrbanCycle [38], UVQ [39], WaterCress [40], Urban Developer model [41] and City Water Balance [33]. The UVQ (Urban Volume and Quality) model [39,42] has been selected to carry out the water and contaminant balance analysis in this study due to its capacity for system integration, and options for consideration of varying spatial scale and water quality which are main requirements of the present integrated system analysis approach. The water and contaminant balance results from this analysis can then be used as one of the major components for evaluation of the hybrid water supply systems. In addition, supply reliability of fit-for-purpose water, defined as the percentage of demand met from the combination of alternative water supply storages over the modeling period will be used for the evaluation of the hybrid water supply system. Supply reliability is estimated based on the daily water balance provided by the UVQ model. 


\subsection{Proposed Ranking Method}

\subsubsection{Scenario Evaluation}

In this segment of the framework, water and contaminant balance outcomes need to be evaluated against the specific objectives set out for water demand and system capacity. Scenarios found to meet these development specific objectives will be considered for Multi-criteria Decision analysis later.

\subsubsection{Ranking of Scenarios}

Several empirical and analytical approaches such as cost benefit analysis, life cycle analysis, community cost incorporating life cycle and environmental cost, and various multi-criteria assessment methods can be employed to provide an integrated assessment of hybrid water supply systems performance [22,31]. Of the various approaches, multi-criteria decision analysis (MCDA) is a technique that explicitly considers the multiple criteria in a decision making environment that aims to improve the transparency, auditability and analytical rigor of these decisions [43]. This approach has been widely utilized for urban water system analysis in several studies [24,44-47]. MCDA evaluates and ranks the finite number of decision options based on the weights of a finite set of criteria [45]. There are several MCDA methods used for water resources management problems. The most commonly applied methods includes fuzzy set analysis, Compromise Programming (CP), Analytic Hierarchy Process (AHP), Elimination et Choice Translating Reality (ELECTRE) and Preference Ranking and Organization Method for Enrichment Evaluation (PROMETHEE) [44]. These methods differ from each other in the methodology they use, the quality and quantity of the extra information they need, the sensitivity tools they offer, their ease of application, the mathematical properties they verify and availability of software [48]. The PROMETHEE method based on a pair-wise comparison $[49,50]$ of options is proposed for this study because of its transparent computational procedure and the comparatively low time and effort needed by the Decision Maker to reach a conclusion [51]. The D-Sight Software [52,53] based on PROMETHEE will used in this study to rank alternative scenarios.

Several criteria along with their weights from Section 3.1.3 can be considered to evaluate the scenarios. Further, preference functions which signify the relative importance of one alternative over another with respect to the adopted evaluation criterion [51] needs to be assessed based on the questionnaire survey among water resource managers, stormwater planners, water supply planners, sewer planners and integrated urban water managers. Scenarios can be ranked based on the weights and preference function of the evaluation criteria; and outputs from hybrid water supply scenario analysis.

\subsubsection{Preferred Set of Scenarios and Future Scenario Analysis}

The preferred sets of scenarios need to be selected from the ranking of scenarios. These scenarios can then be modelled to determine the impacts of climatic and demographic changes. Such an approach helps in identifying the hybrid water supply scenario that performs best under a range of conditions. This analysis assists in identifying a resilient system. In this study, a resilient system is defined as a system that is able to absorb disturbances and still remain within the same state, reorganize itself while undergoing changes so as to still retain essentially the same function, and build and increase the capacity for adaptation [54]. The concept of a resilient system has been adopted considering its suitability for water supply and wastewater infrastructures [55].

As discussed earlier, this study demonstrates a part of the proposed framework. Specifically, a subset of this evaluation framework (indicated in blue color in Figure 2) is applied in the Northern Growth Area (NGA) of Melbourne (Figure 3), Australia as presented in the next section. 


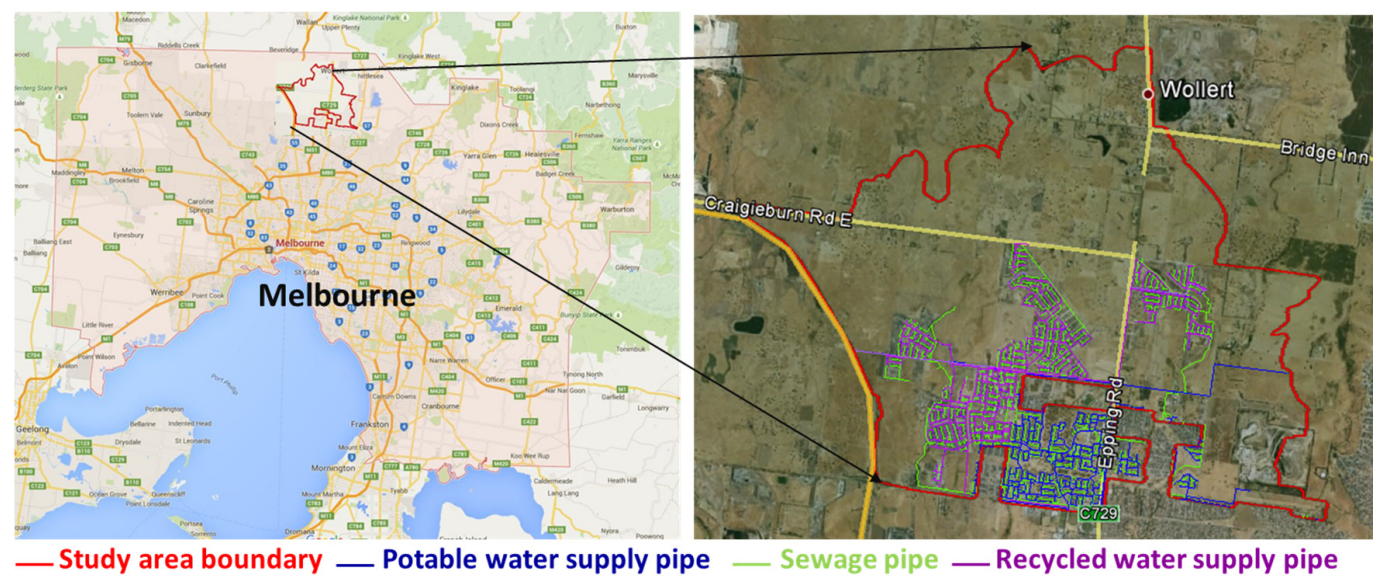

Figure 3. Location map of study area.

\section{Case Study Application}

The Northern Growth Area (NGA) of Melbourne, Australia consisting of the urban development of Aurora, Epping North East, Quarry Hill and Wollert, is located approximately $20 \mathrm{~km}$ north from the Melbourne CBD. It is supplied with Class A recycled water from the Aurora wastewater treatment plant via third pipe for non-potable use which includes toilet flushing, garden watering, car washing and irrigation of public open space.

This section presents the systematic implementation of the methodology developed in this study and the analysis approach designed to understand the impacts of hybrid water supply systems.

The study area covers 2257 hectares of land. Based on the Google map accessed on 27 August 2012, there were 3455 residential households, a sport complex and a shopping complex. For modelling purpose, a residential area of $450 \mathrm{~m}^{2}$ with roof area of $300 \mathrm{~m}^{2}$, paved area of $60 \mathrm{~m}^{2}$ and garden area of $90 \mathrm{~m}^{2}$ was considered [56]. In addition, this study considers a household occupancy rate of 2.86 people per household [57]. Table 1 presents indoor water demand for residence provided by the local water utility Yarra Valley Water (YVW). Water use for toilet in commercial lots has been calculated assuming the equivalent of 180 users per day based on the technical report by Sharma, et al. [58]. Garden irrigation demand is based on soil moisture level and is calculated within the model.

Table 1. Indoor water demand for residential purposes.

\begin{tabular}{cc}
\hline Use & Demand (L/Cap/Day) \\
\hline Toilet & 21.6 \\
Bathroom & 62.5 \\
Laundry & 26.8 \\
Kitchen & 22.7 \\
\hline
\end{tabular}

Climate data was adopted from Bureau of Meteorology, Australia records. A period of 34 years (1980-2013) was used for the water balance analysis of the area which has an annual average rainfall of $642 \mathrm{~mm}$ and pan evaporation of $1198 \mathrm{~mm}$. GIS maps for potable/recycled water and sewage infrastructures were collected from YVW and stormwater drainage from Melbourne water. These maps provide the layout of the water supply and wastewater/stormwater networks together with their flow capacity. This information helped set the limits of the feasible ranges of water, wastewater and stormwater flow rate and contaminant concentration.

The water supply options assessed for the study area include centralized supply (conventional reticulated system), a third pipe system supplying treated wastewater or reclaimed water, rainwater tanks and greywater systems. Based on the most common integrated water management approaches 
adopted globally, the alternative water supply options includes rainwater, stormwater, wastewater and greywater reuse [31]. Current practices in Melbourne, Australia have adopted similar approaches [59].

Two typical scenarios are compared to illustrate the application of this framework. These scenarios include:

I Scenario 1: This conventional scenario considers only a centralized water supply system scenario where the entire water demand is met by potable water. Please refer to the schematic diagram of the scenario in Figure A1. This scenario represents the conventional water supply system.

II Scenario 2: The centralized system is combined with treated recycled water (Class A water) via 3rd pipe. This scenario represents a typical scenario that illustrates the effects of a decentralized water supply option on the centralized water infrastructure. In addition, this case reflects the existing water supply system in the area. In this scenario (as shown in Figure A2), wastewater is collected at development level and distributed through a dual reticulation system for toilet flushing and garden irrigation after treatment. The remaining water demand is met from potable water supply. The implementation of this alternative system must always consider the use of suitable wastewater technology and its management to prevent any contamination risk from the recycled water. This aspect, however, is not dealt within the scope of this paper.

As discussed earlier the water and contaminant balance analysis is conducted using the UVQ (Urban Volume and Quality) model [39]. The water balance analysis estimates volume and flow rate of potable water, stormwater and wastewater along with flow quantities of wastewater reuse. The UVQ function enables the estimation of the contaminants balance and loads including TSS, $\mathrm{TP}, \mathrm{TN}, \mathrm{BOD}$ and COD. Here, contaminant balance estimates are based on the water volumes calculated in the water balance and user specified concentrations, loads and performance criteria. Removal percentage of specified contaminants with the use of different wastewater and stormwater technologies are obtained from the literature [60] and from data available from Yarra Valley Water (YVW), Victoria. The removal efficiency for treated waste water is calculated based on the actual data from Yarra Valley Water for raw effluent going to the treatment plant and Class A recycled water. The measured quality of Class A recycled water is aligned with water quality guidelines provided by EPA (Environmental Protection Agency), Victoria as shown in Table A1. The estimated values of TN, TP, TSS, BOD and COD are $98.1 \%, 99.32 \%, 99.62 \%, 99.61 \%$ and $99.61 \%$, respectively.

The model was run over a 34-year time series of climate data at daily time step to simulate seasonal and annual climate variability. For Scenario 2, a recycled water tank size of $1.0 \mathrm{~mL}$ was adopted consistent with the actual recycled water tank size used in the area. The supply reliability of the tank found that $96 \%$ of non-potable water demand (garden water and toilet water in this case) is met from the alternative water supply storage (treated wastewater) over the modeling period while the rest is provided from the centralized system. This reliability, which depends on the size of wastewater storage tank, is calculated based on the daily water balance. Treated wastewater could not meet the full demand despite the annual supply of wastewater being greater than the total annual demand for toilets and gardens because sufficient wastewater cannot be stored and given the seasonal variation in garden demand. Hence, increasing the size of recycled water tank can increase the system reliability. For instance, in this particular scenario, using a $1.1 \mathrm{~mL}$ tank would have met all the required demand. The water and contaminant balance summary along with the supply reliability of the two scenarios is presented in Table A2. The removal efficiency for treated wastewater is calculated based on the data from Yarra Valley Water for raw effluent going into the treatment plant and Class A recycled water. Figure 4 below presents the change in potable water flow, wastewater flow, wastewater contaminants and supply reliability.

Scenario 2 requires $16.97 \%$ less potable water and generates $24.64 \%$ less wastewater compared to Scenario 1 . However, Scenario 2 results in increased contaminant concentration in wastewater by almost $32 \%$. This is because the residual contaminants from decentralized local wastewater treatment 
are assumed to be disposed of to the main sewer. However, all the contaminant concentrations fall within the range of contaminant concentration for typical untreated domestic wastewater (Table A3) based on the existing literature [61-63] except for total phosphorous which is slightly higher. Based on the nature of decentralized wastewater treatment process, an appropriate sludge management approach needs to be adopted.

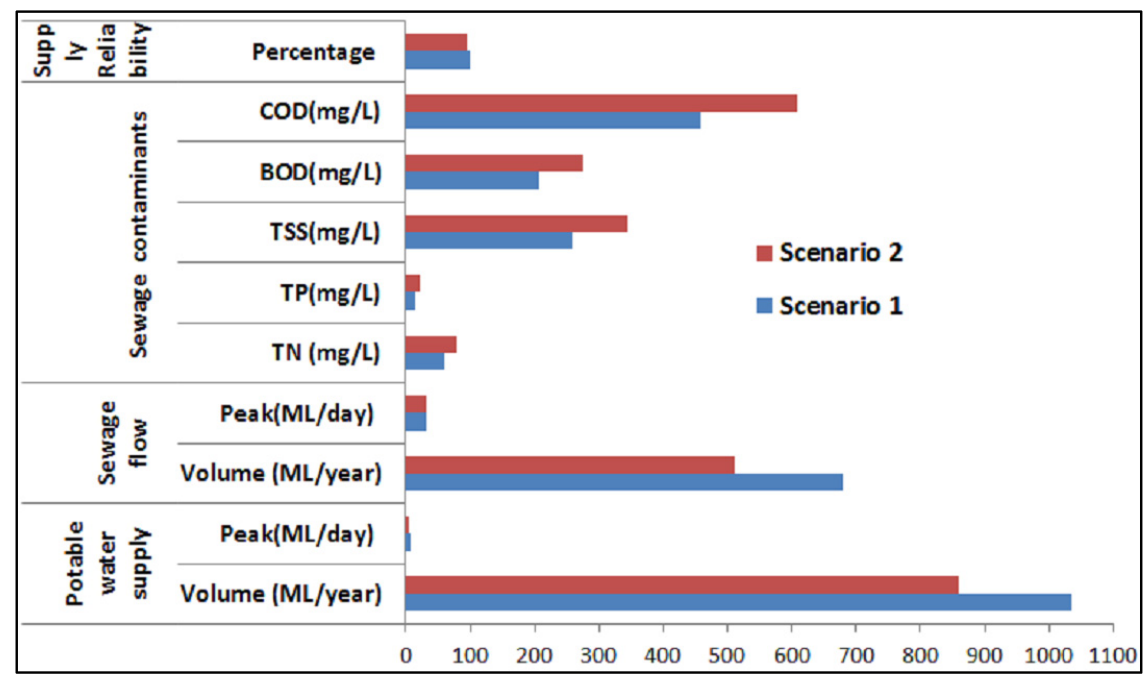

Figure 4. Average water output for the two scenarios for the selected criteria.

This study models two scenarios to estimate water and contaminant balance to demonstrate the application of the proposed framework. The baseline setting of the two scenarios was found to meet the specific objectives related to water demand and system capacity. To evaluate the impacts of changed demographics and climatic conditions, the two scenarios are subjected to the following perturbations:

I Condition $1-$ Scenarios are run with $10 \%$ increase in population

II Condition 2-Scenarios are run with changed climatic condition at a daily time scale. Climate data (Precipitation and Temperature) from 2030-2055 based on the RCP (Representative Concentration Pathway) 8.5 high emission scenarios are chosen for illustration purpose. RCP 8.5 is based on rising radiative forcing pathways leading to $8.5 \mathrm{~W} / \mathrm{m}^{2}(\sim 1370 \mathrm{ppm}$ $\mathrm{CO}_{2}$ eq) by 2100 [64]. This scenario represents a High RCP characterized by increasing greenhouse gas emissions over time that lead to high greenhouse gas concentration levels [64]. A high RCP scenario was chosen for this analysis to represent the worst-case future scenario. Detail information of calculations related to greenhouse gas concentration is adopted from Meinshausen et al. (2011) [65]. In this scenario, average and maximum temperature increase is predicted to be $10 \%$ and $7 \%$, respectively. Maximum precipitation increases by $0.3 \%$, mean precipitation decrease by $1.1 \%$ and the number of wet days (precipitation $\geqslant 1 \mathrm{~mm} /$ day) decreases by $4.6 \%$.

A summary of the water and contaminant balance for these scenarios and changed conditions is provided in Table A4. The comparison of scenarios 1 and 2 based on 2012 population level (Figure 4) shows a change in potable water and sewage flow. The change in potable water and wastewater variables in response to demographic and climatic changes is shown in Figure 5. Scenario 1 is taken as base scenario and assigned a value of one for variables set to 2012 levels. For other scenarios, variables are taken as a ratio between the variables of the respective scenario and the base Scenario 1 for 2012 population level.

When comparing the two scenarios for the changed conditions, it is found, as expected, that population changed conditions have major impacts on potable water use. Further, it is observed 
that the use of treated wastewater along with centralized supply can provide the extra water needed for the area with less change in daily average peak potable water supply flow. 3.97\% decrease in potable water supply peak is observed for Scenario 2 compared to $14.90 \%$ increase in Scenario 1 for the increased population level. For the changed climatic condition, potable water supply volume is found to increase by $3.81 \%$. This is primarily due to the additional use of potable water for garden irrigation as average precipitation is lower in the RCP 8.5 climate scenario. The wastewater flow volume increases by $5.84 \%$ with the increase in population, however, a negligible increase in peak flow is observed. The peak wastewater flow is mainly governed by wet flow which includes sanitary flow and a portion of storm water flow. For climate change, the volume of wastewater increases by $4.76 \%$ because there is an increase in the numbers of higher intensity rainfall events in the RCP 8.5 climate scenarios. No significant difference is observed in the maximum (peak) wastewater flow as there is only $0.3 \%$ increase of maximum precipitation accompanied by an increase in average temperature of $7.0 \%$.

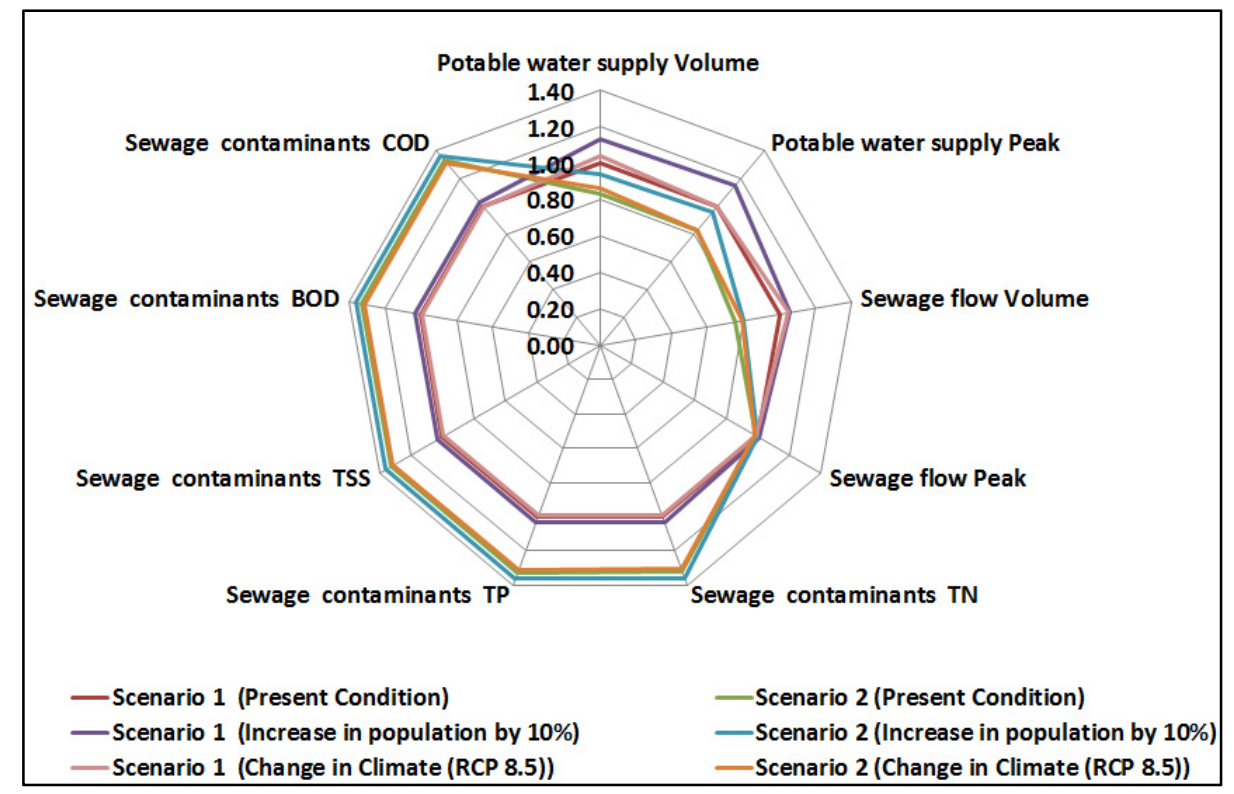

Figure 5. Spider diagram comparing two scenarios in various conditions.

Figure 6 shows the box plot of daily potable water use for the two scenarios under climate and population change conditions. The plot suggests that scenario 2 under all conditions has a narrow range of variation compared to scenario 1 . In addition, scenario 2 has a lower-volume of maximum daily potable water supply in all the cases which makes it more resilient under the changed condition relative to scenario 1 .

Figure 7 shows the box plot of daily sewage outflow for the two scenarios for changed climate and perturbated population levels. The overall box plot shows a large variation in high flows. It is because high flows not only include dry weather (sanitary) flow but also groundwater non-rainfall dependent infiltration, and rainfall dependent inflow. Despite the existence of a separate collection system, it is virtually impossible to isolate sewage system from storm rainfall [66]. As shown in Tables A2 and A4 climate change has no significant effects on the contaminant concentration of wastewater. These results also show that when population increases, contaminant concentration in the wastewater increases in the centralized system. While comparing Scenario 2 under population increase condition with Scenario 2 of 2012, the wastewater concentration is observed to increase. This can be ascribed to an increase in population and an increase in the reuse of wastewater. 


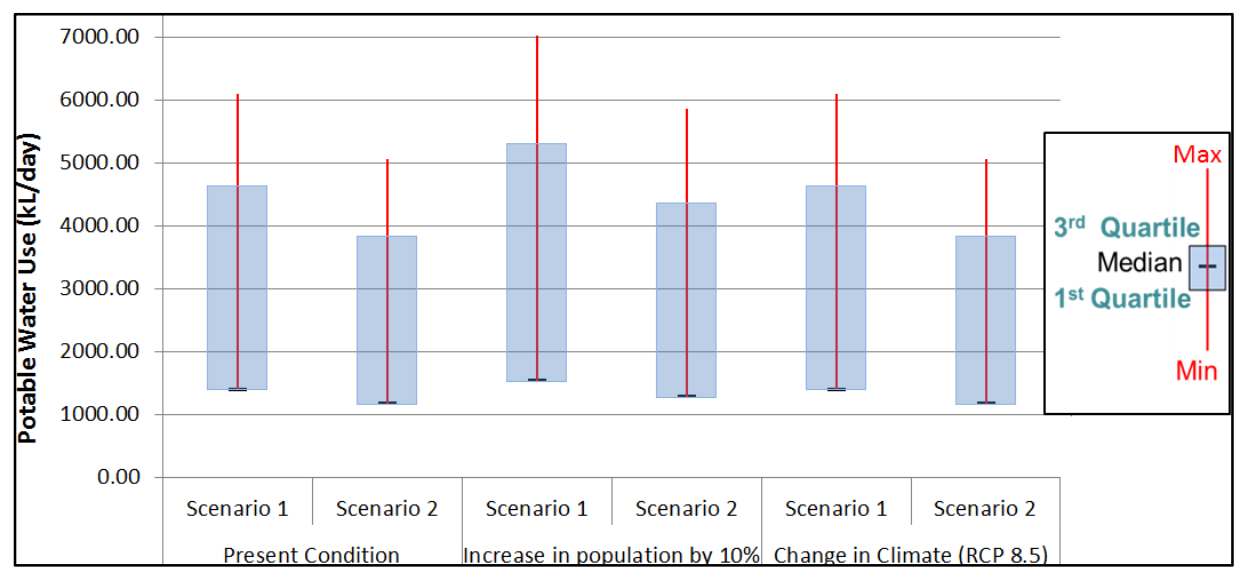

Figure 6. Box plot of potable water use under two scenarios for changes in population and climate.

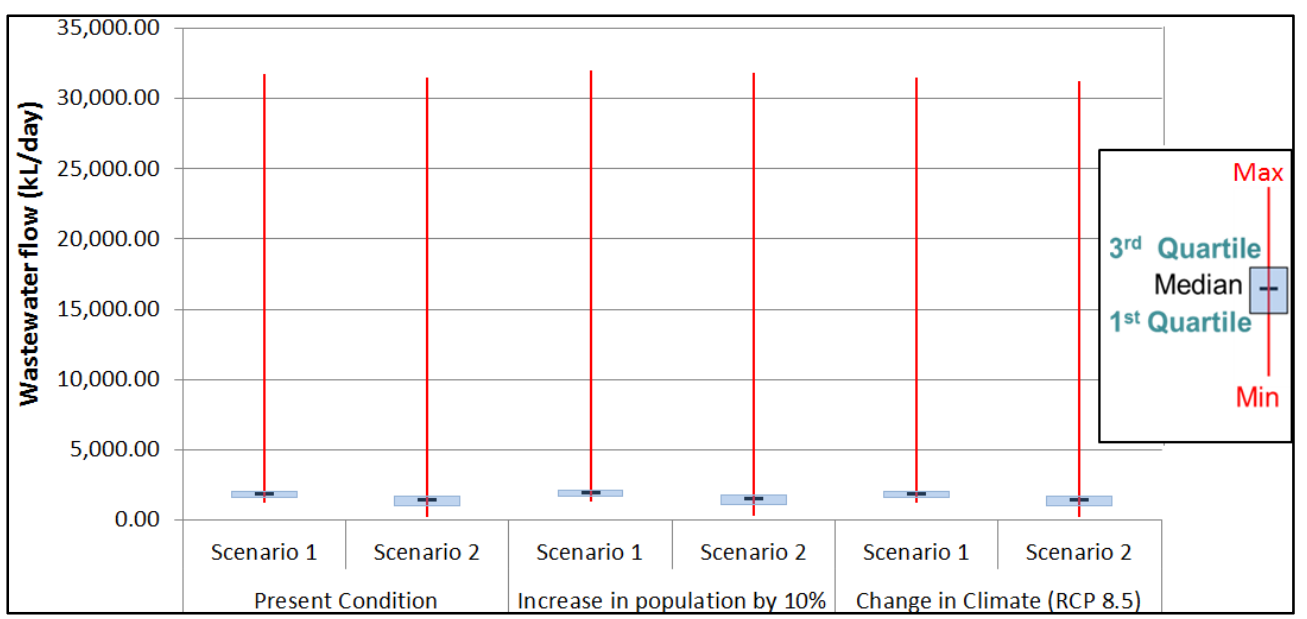

Figure 7. Box plot of wastewater flow under two scenarios for changes in population and climate.

\section{Discussion}

This study provides a comprehensive framework to evaluate the impacts of hybrid centralized and decentralized urban water supply systems which are increasingly being considered as a viable option for meeting increasing water demand under resource scarcity and the use of a diversity of supply options. In this study, we have analytically demonstrated that there are likely interactive impacts from the implementation of hybrid WSS that can have implications on the operation and performance of existing centralized infrastructure including possible impacts on changes in wastewater and stormwater quantity and quality.

Proposed framework is illustrated through the applications on the Northern Growth Area, a recent urban development in Melbourne, Australia. In this case study, a combination of a typical centralized water supply system with treated waste water system is assessed to estimate changes in water and contaminant balance in relation to a centralized only system. The results from water and contaminant balance modelling show that the use of hybrid water supply systems reduces the potable water demand significantly (1036 to $860 \mathrm{~mL} /$ year). Further, wastewater flow is also reduced from $678 \mathrm{~mL} /$ year to $511 \mathrm{~mL} /$ year. Conversely, wastewater contaminant concentration for TN, TP, TSS, BOD and COD increases for the hybrid scenario by almost $32 \%$.

In addition, the two water supply scenarios were evaluated for changes in demographics and population. When compared to the centralized-only system, the hybrid water supply scenario is found to be more resilient in terms of adjusting to the changing population and climatic conditions 
as less variation is observed in potable water demand. In this way, the case study findings help to demonstrate that the framework is suitable to assess the impacts of hybrid water supply systems.

In future, this study will consider wider ranges of scenarios and assess them using multi-criteria decision analysis as a tool to rank their performance. The water and contaminant balance resulting from the analysis can be used as one of the main elements in the evaluation of hybrid water supply systems.

This study, however, has some limitations that need to be taken into account in future research. First, it has not considered social behavior and local acceptance of hybrid water supply systems. A more qualitative study is required to identify the perception of people which is beyond the scope of this study [67]. Second, this research does not take into account the energy usage and economic aspects of hybrid water supply system. However, the evaluation framework presented in this study is sufficiently flexible to incorporate the socio-economic dimensions if so required. Therefore, the current framework should only be used to assess the physical interaction of hybrid WSS with centralized water system in terms of flow and variations in contaminant loads. In the context of public health protection, it is assumed that the application of this framework must always consider the relevant legal and health regulations.

\section{Conclusions}

This study presents an evaluation framework coupled with water and contaminant balance modelling, future scenario analysis and multi-criteria decision analysis to assess the interaction between centralized and decentralized water systems. Using this framework, hybrid water supply scenario is analyzed for its impacts on potable water, wastewater and stormwater flows. Case study application demonstrates that the use of alternative water supply options combined with centralized water supply system can significantly reduce potable water demand and alter wastewater flow and contaminant concentration. For instance, hybrid water supply scenario uses $16.97 \%$ less potable water and generates $24.64 \%$ less waste water flow compared to conventional centralized scenario. Conversely, wastewater concentration is increased by $32 \%$. The study also shows that use of the hybrid water supply scenario reduces the variability in potable water use $(1.16-5.05(\mathrm{~mL} /$ day $))$ compared to conventional system (1.4-6.11 ( $\mathrm{mL} /$ day)). These scenarios are also evaluated for changes in demographics and population. Results show population change has more significant effect on potable water use compared to climate change. For Scenario 1, potable water supply volume and peak is changed by $13.31 \%$ and $14.90 \%$ for increased population condition. For climate change condition, only potable water supply volume was increased by $3.81 \%$. Wastewater flow volume is increased by $5.84 \%$ and $4.76 \%$ respectively, for changed climatic and demographic conditions respectively compared to Scenario 1 of 2012. Hybrid scenario is found to provide extra water needed for the area with relatively less change in daily average peak potable water supply under the changed condition.

Hence, this framework contributes in understanding and implementing hybrid water supply system in an objective manner which is crucial in the development of more sustainable and resilient urban infrastructure system. In the context of climate change and population growth this study framework adds further value to develop resilient urban water infrastructure systems. In this way, the case study findings helped to demonstrate that the framework is suitable to assess hybrid water supply systems. Moreover, this framework contributes in understanding and implementing hybrid water supply system in an objective manner which is crucial in the development of more sustainable and resilient urban infrastructure system. In the context of climate change and population growth this study framework adds further value to develop resilient urban water infrastructure systems. The use of such framework can help water managers to make informed decisions involving the combination of decentralized and centralized systems under a variety of population and climate scenarios.

Acknowledgments: The authors would like to thank Yarra Valley Water (Melbourne, Australia), Melbourne Water (Melbourne, Australia) and Bureau of Meteorology (Melbourne, Australia) for providing the data. 
Mukta Sapkota is conducting this PhD study with funding support from the Australian Government and the Melbourne University.

Author Contributions: All authors were involved in designing and discussing the study. Mukta Sapkota drafted and finalized the manuscript. She executed the model. Meenakshi Arora, Hector Malano, Magnus Moglia, Ashok Sharma, Biju George and Francis Pamminger supervised the research. All authors discussed the results and implications and commented on the manuscripts at all the stages.

Conflicts of Interest: The authors declare no conflict of interest.

\section{Appendix}

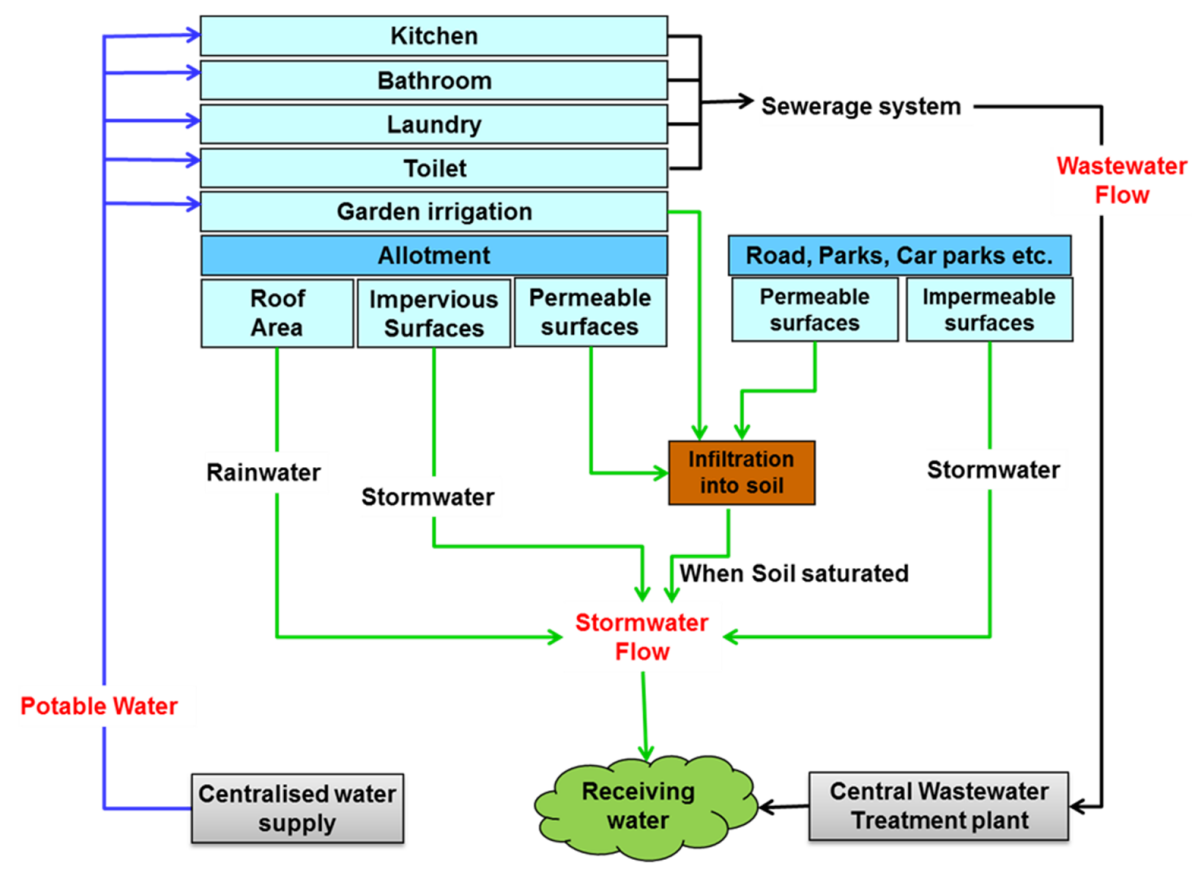

Figure A1. Schematic diagram of Scenario 1.

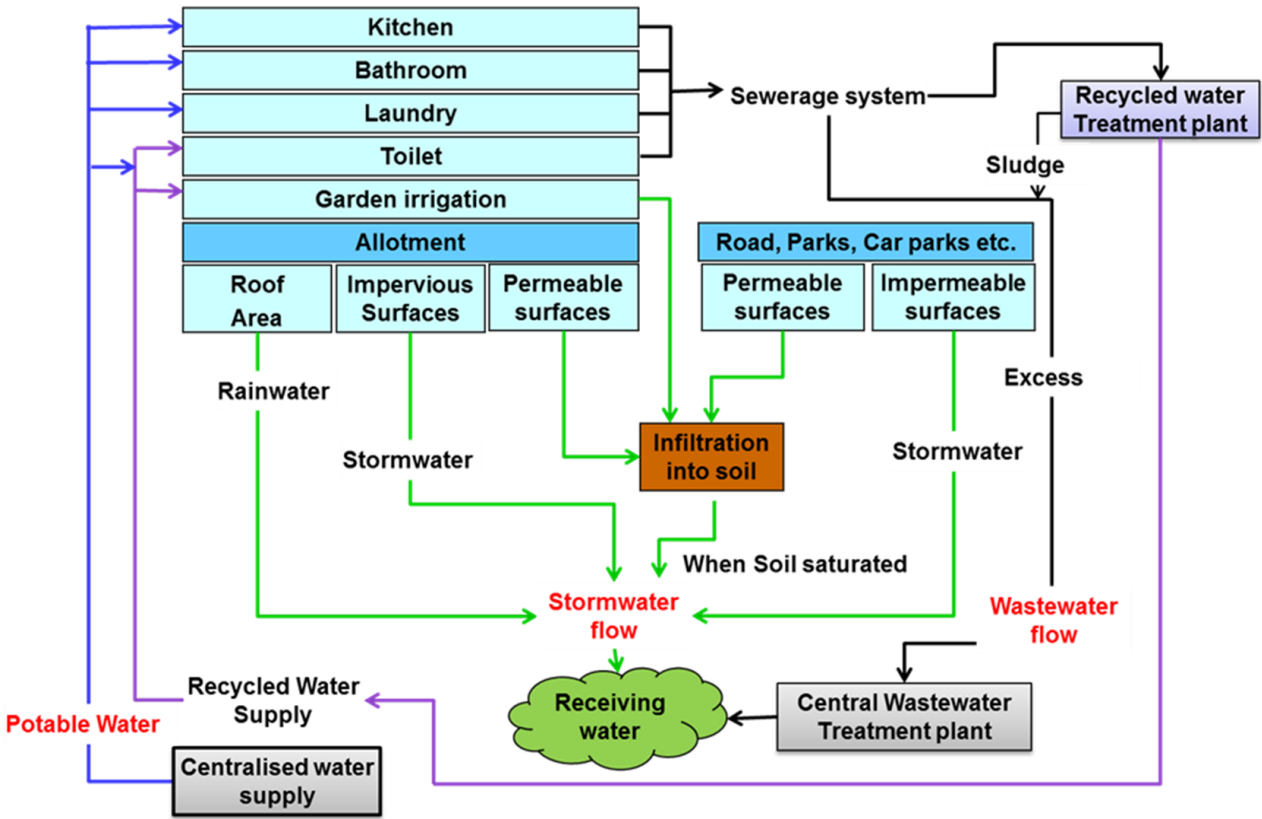

Figure A2. Schematic diagram of Scenario 2. 
Table A1. Water Quality for Class A recycled water.

\begin{tabular}{ccc}
\hline Measure & EPA Guidelines [68] & $\begin{array}{c}\text { Observed at Aurora (12 Month } \\
\text { Period from July 2010-June 2011 }\end{array}$ \\
\hline E. coli & $\begin{array}{c}\text { Median over 12 months } \\
(<10 \text { organisms } / 100 \mathrm{~mL})\end{array}$ & 0 organisms $/ 100 \mathrm{~mL}$ \\
\hline $\begin{array}{c}\text { Biochemical Oxygen } \\
\text { Demand (BOD) }\end{array}$ & $<10 \mathrm{mg} / \mathrm{L}$ & $1.18 \mathrm{mg} / \mathrm{L}$ \\
\hline Suspended Solids (SS) & $<5 \mathrm{mg} / \mathrm{L}$ & $1.86 \mathrm{mg} / \mathrm{L}$ \\
\hline Turbidity & $<5 \mathrm{NTU}$ & $1.06 \mathrm{NTU}$ \\
\hline $\mathrm{pH}$ & $6-9$ & $6.9-7.8$ \\
\hline
\end{tabular}

Table A2. Average water outputs for the scenario.

\begin{tabular}{cccc}
\hline \multirow{2}{*}{ Criteria } & \multirow{2}{*}{ Sub Criteria } & \multicolumn{2}{c}{ Scenarios } \\
\cline { 3 - 4 } & & $\mathbf{1}$ & $\mathbf{2}$ \\
\hline \multirow{2}{*}{ Potable water supply } & Volume $(\mathrm{mL} /$ year $)$ & 1036 & 860 \\
& Peak day $(\mathrm{mL} /$ day) & 6.11 & 5.05 \\
\hline \multirow{2}{*}{ Sewage flow } & Volume $(\mathrm{mL} /$ year $)$ & 678 & 511 \\
& Peak day $(\mathrm{mL} /$ day) & 31.74 & 31.52 \\
\hline \multirow{2}{*}{ Stormwater flow } & Volume $(\mathrm{mL} /$ year $)$ & 2490 & 2490 \\
& Peak day $(\mathrm{mL} /$ day $)$ & 1808 & 1808 \\
\hline \multirow{2}{*}{ Sewage contaminants concentration } & TN $(\mathrm{mg} / \mathrm{L})$ & 59.1 & 78.1 \\
& TP $(\mathrm{mg} / \mathrm{L})$ & 15.5 & 20.6 \\
& TSS $(\mathrm{mg} / \mathrm{L})$ & 259.3 & 343.7 \\
& BOD $(\mathrm{mg} / \mathrm{L})$ & 207.5 & 275.1 \\
& COD $(\mathrm{mg} / \mathrm{L})$ & 459.2 & 608.7 \\
\hline \multirow{2}{*}{ Stormwater contaminants loads } & TN $(\mathrm{kg} /$ year $)$ & 4856 & 4856 \\
& TP $(\mathrm{kg} /$ year $)$ & 375 & 375 \\
& TSS $(\mathrm{kg} /$ year $)$ & 101,349 & 101,349 \\
& BOD $(\mathrm{kg} /$ year $)$ & 14,951 & 14,951 \\
& COD $(\mathrm{kg} /$ year $)$ & 69,995 & 69,995 \\
\hline Supply Reliability & Percentage & 100 & 96 \\
\hline
\end{tabular}

Table A3. Contaminant Concentration of typical untreated domestic wastewater (Adapted from Various literatures).

\begin{tabular}{lccc}
\hline \multicolumn{1}{c}{ Contaminants } & $\begin{array}{c}\text { Untreated } \\
\text { Domestic } \\
\text { Wastewater [61] }\end{array}$ & $\begin{array}{c}\text { Untreated } \\
\text { Domestic } \\
\text { Wastewater [62] }\end{array}$ & $\begin{array}{c}\text { Untreated Municipal Wastewater } \\
\text { with Minor Contributions of } \\
\text { Industrial Wastewater [63] }\end{array}$ \\
\hline Total Nitrogen (TN) (mg/L) & $20-85$ & $20-85$ & $30-100$ \\
\hline $\begin{array}{l}\text { Total Phosphorous (TP) } \\
\text { (mg/L) }\end{array}$ & $4-15$ & $6-20$ & $6-25$ \\
\hline $\begin{array}{l}\text { Total Suspended Solids } \\
\text { (TSS) }(\mathrm{mg} / \mathrm{L})\end{array}$ & $100-350$ & $100-350$ & $250-600$ \\
\hline BOD $(\mathrm{mg} / \mathrm{L})$ & $110-400$ & $100-300$ & $230-560$ \\
\hline COD $(\mathrm{mg} / \mathrm{L})$ & $250-1000$ & - & $500-1200$ \\
\hline
\end{tabular}


Table A4. Average water outputs for different scenarios in various conditions.

\begin{tabular}{cccccc}
\hline \multirow{2}{*}{ Criteria } & \multirow{2}{*}{ Sub Criteria } & \multicolumn{4}{c}{ Condition } \\
\cline { 3 - 6 } & & Population Increase by 10\% & \multicolumn{1}{c}{ Climate Change (RCP 8.5) } \\
\cline { 3 - 6 } & & Scenario 1 & Scenario 2 & Scenario 1 & Scenario 2 \\
\hline \multirow{2}{*}{ Potable water supply } & Volume (mL/year) & 1174 & 978 & 1075 & 893 \\
& Peak day (mL/day) & 7.02 & 5.86 & 6.11 & 5.05 \\
\hline \multirow{2}{*}{ Sewage flow } & Volume (mL/year) & 718 & 542 & 710 & 537 \\
& Peak day (mL/day) & 32.04 & 31.80 & 31.47 & 31.25 \\
\hline \multirow{2}{*}{ Stormwater flow } & Volume (mL/year) & 2579 & 2579 & 2583 & 2583 \\
& Peak day (mL/day) & 1822 & 1822 & 1794 & 1794 \\
\hline \multirow{3}{*}{ Sewage contaminants } & TN (mg/L) & 60.9 & 80.4 & 58.7 & 77.3 \\
concentration & TP (mg/L) & 16.0 & 21.2 & 15.4 & 20.4 \\
& TSS (mg/L) & 266.8 & 353.1 & 257.4 & 340.2 \\
& BOD (mg/L) & 213.6 & 282.6 & 206.0 & 272.3 \\
& COD (mg/L) & 472.5 & 625.4 & 455.8 & 602.5 \\
\hline \multirow{2}{*}{ Stormwater } & TN (kg/year) & 5101 & 5101 & 4832 & 4832 \\
contaminants loads & TP (kg/year) & 394 & 394 & 373 & 373 \\
& TSS (kg/year) & 107,079 & 107,079 & 100,635 & 100,635 \\
& BOD (kg/year) & 15,907 & 15,907 & 14,802 & 14,802 \\
\hline Supply Reliability & COD (kg/year) & 74,578 & 74,578 & 69,297 & 69,297 \\
\hline
\end{tabular}

\section{References}

1. Sitzenfrei, R.; Rauch, W. Investigating transitions of centralized water infrastructure to decentralized solutions-An integrated approach. Procedia Eng. 2014, 70, 1549-1557. [CrossRef]

2. Marlow, D.R.; Moglia, M.; Cook, S.; Beale, D.J. Towards sustainable urban water management: A critical reassessment. Water Res. 2013, 47, 7150-7161. [CrossRef] [PubMed]

3. Lee, S.; Yigitcanlar, T.; Egodawatta, P.K.; Goonetilleke, A. Sustainable water provision: Challenges, alternative strategies and sources in the era of climate change. In Sustainable Urban and Regional Infrastructure Development: Technologies, Applications and Management; Yigitcanlar, T., Ed.; IGI Global: Hershey, PA, USA, 2010; pp. 17-30.

4. Sapkota, M.; Arora, M.; Malano, H.; Moglia, M.; Sharma, A.; George, B.; Pamminger, F. An overview of hybrid water supply systems in the context of urban water management: Challenges and opportunities. Water 2015, 7, 153-174. [CrossRef]

5. Schramm, E.; Felmeden, J. Towards more resilient water infrastructures. In Resilient Cities 2: Cities and Adaptation to Climate Change-Proceedings of the Global Forum 2011; Otto-Zimmermann, K., Ed.; Springer: Berlin, Germany, 2012; Volume 2, pp. 177-186.

6. Großmann, K.; Bontje, M.; Haase, A.; Mykhnenko, V. Shrinking cities: Notes for the further research agenda. Cities 2013, 35, 221-225. [CrossRef]

7. Daigger, G.T. Evolving urban water and residuals management paradigms: Water reclamation and reuse, decentralization, and resource recovery. Water Environ. Res. 2009, 81, 809-823. [CrossRef] [PubMed]

8. Swamee, P.K.; Bhargava, R.; Sharma, A. Noncircular sewer design. J. Environ. Eng. 1987, 113, 824-833. [CrossRef]

9. Sharma, A.K.; Tjandraatmadja, G.; Cook, S.; Gardner, T. Decentralised systems-Definition and drivers in the current context. Water Sci. Technol. 2013, 67, 2091-2101. [CrossRef] [PubMed]

10. Skinner, R. Adaptation to climate change in melbourne: Changing the fundamental planning assumptions. In International Adaptation Forum on Climate Change Impacts on Water Supply, Washington, DC, USA, 27 January 2010; p. 24.

11. Rozos, E.; Makropoulos, C. Assessing the combined benefits of water recycling technologies by modelling the total urban water cycle. Urban Water 2012, 9, 1-10. [CrossRef]

12. Gikas, P.; Tchobanoglous, G. The role of satellite and decentralized strategies in water resources management. J. Environ. Manag. 2009, 90, 144-152. [CrossRef] [PubMed] 
13. Bieker, S.; Cornel, P.; Wagner, M. Semicentralised supply and treatment systems: Integrated infrastructure solutions for fast growing urban areas. Water Sci. Technol. 2010, 61, 2905-2913. [CrossRef] [PubMed]

14. Weber, B.; Cornel, P.; Wagner, M. Semi-centralised supply and treatment systems for (fast growing) urban areas. Water Sci. Technol. 2007, 55, 349-356. [CrossRef] [PubMed]

15. Coombes, P.J.; Kuczera, G. Integrated urban water cycle management: Moving towards system understanding. In Proceedings of the 2nd National Conference on Water Sensitive Urban Design, Brisbane, Australia, 2-4 September 2002.

16. Butler, D.; Makropoulos, C. Water Related Infrastructure for Sustainable Communities; Environment Agency: Bristol, UK, 2006; p. 125.

17. Makropoulos, C.K.; Butler, D. Distributed water infrastructure for sustainable communities. Water Resour. Manag. 2010, 24, 2795-2816. [CrossRef]

18. Sharma, A.; Cook, S.; Tjandraatmadja, G.; Gregory, A. Impediments and constraints in the uptake of water sensitive urban design measures in greenfield and infill developments. Water Sci. Technol. 2012, 65, 340-352. [CrossRef] [PubMed]

19. Tjandraatmadja, G.; Burn, S.; McLaughlin, M.; Biswas, T. Rethinking urban water systems: Revisiting concepts in urban wastewater collection and treatment to ensure infrastructure sustainability. Water Sci. Technol. Water Supply 2005, 5, 145-154.

20. Marleni, N.; Gray, S.; Sharma, A.; Burn, S.; Muttil, N. Impact of water source management practices in residential areas on sewer networks-A review. Water Sci. Technol. 2012, 65, 624-642. [CrossRef] [PubMed]

21. Sapkota, M.; Arora, M.; Malano, H.; George, B.; Nawarathna, B.; Sharma, A.; Moglia, M. Development of a Framework to Evaluate the Hybrid Water Supply Systems. In Proceedings of the 20th International Congress on Modelling and Simulation, Adelaide, Australia, 1-6 December 2013; pp. 2387-2393.

22. Poustie, M.S.; Deletic, A.; Brown, R.R.; Wong, T.; de Haana, F.J.; Skinner, R. Sustainable urban water futures in developing countries: The centralised, decentralised or hybrid dilemma. Urban Water 2015, 12. [CrossRef]

23. Cook, S.; Tjandraatmadja, G.; Marleni, N. Impact of Source Management Strategies On quality and Loads in Residential Wastewater-Scenario Analysis; CSIRO Water for a Healthy Country National Research Flagship: Melbourne, Australia, 2010.

24. Abrishamchi, A.; Ebrahimian, A.; Tajrishi, M.; Mariño, M.A. Case study: Application of multicriteria decision making to urban water supply. J. Water Resour. Plan. Manag. 2005, 131, 326-335. [CrossRef]

25. Libralato, G.; Ghirardini, A.V.; Avezzù, F. To centralise or to decentralise: An overview of the most recent trends in wastewater treatment management. J. Environ. Manag. 2012, 94, 61-68. [CrossRef] [PubMed]

26. Hering, J.G.; Waite, T.D.; Luthy, R.G.; Drewes, J.E.; Sedlak, D.L. A changing framework for urban water systems. Environ. Sci. Technol. 2013, 47, 10721-10726. [CrossRef] [PubMed]

27. Coombes, P.J.; Cullen, A.; Bethke, K. Towards sustainable cities-Integrated water cycle management (iwcm) at the existing principal activity centre at doncaster hill. In Proceedings of the 34th World Congress of the International Association for Hydro-Environment Research and Engineering: 33rd Hydrology and Water Resources Symposium and 10th Conference on Hydraulics in Water Engineering, Brisbane, Australia, 26 June-1 July 2011; Valentine, E.M., Apelt, C.J., Ball, J., Chanson, H., Cox, R., Ettema, R., Kuczera, G., Lambert, M., Melville, B.W., Sargison, J.E., Eds.; Engineers Australia: Barton, Australia, 2011; pp. 2631-2638.

28. Graddon, A.R.; Kuczera, G.; Hardy, M.J. A flexible modelling environment for integrated urban water harvesting and re-use. Water Sci. Technol. 2011, 63, 2268-2278. [CrossRef] [PubMed]

29. Graddon, A.R.; Kuczera, G.; Hardy, M.J. The modelling of urban water supply, harvesting and recycling systems using network linear programs. In Proceedings of the H2009: 32nd Hydrology and Water Resources Symposium, Barton, Australia, 30 November-3 December 2009; Engineers Australia: Newcastle, Australia, 2009; pp. 865-876.

30. Sharma, A.K.; Cook, S.; Chong, M.N. Monitoring and validation of decentralised water and wastewater systems for increased uptake. Water Sci. Technol. 2013, 67, 2576-2581. [CrossRef] [PubMed]

31. Sharma, A.; Grant, A.L.; Grant, T.; Pamminger, F.; Opray, L. Environmental and economic assessment of urban water services for a greenfield development. Environ. Eng. Sci. 2009, 26, 921-934. [CrossRef]

32. Cook, S.; Sharma, A.; Chong, M. Performance analysis of a communal residential rainwater system for potable supply: A case study in brisbane, australia. Water Resour. Manag. 2013, 27, 4865-4876. [CrossRef] 
33. Last, E.M. City Water Balance a New Scoping Tool for Integrated Urban Water Management Options. Ph.D. Thesis, The University of Birmingham, Birmingham, UK, 2010.

34. Mousseau, V. Eliciting information concerning the relative importance of criteria. In Advances in Multicriteria Analysis; Pardalos, P.M., Siskos, Y., Zopounidis, C., Eds.; Springer-Verlag: Berlin, Germany, 1995; pp. 17-43.

35. Mitchell, V.G.; Mein, R.G.; McMahon, T.A. Modelling the urban water cycle. Environ. Model. Softw. 2001, 16, 615-629. [CrossRef]

36. Maheepala, S.; Leighton, B.; Mirza, F.; Rahilly, M.; Rahman, J. Hydro planner-A linked modelling system for water quantity and quality simulation of total water cycle. In OzWater 07 Conference; Australian Water Services Association: Sydney, Australia, 2007.

37. Stewardson, M.J.; Clark, R.D.S.; Cresswell, D.J.; McMahon, T.A. Modelling to assist integrated management of urban water resources. In Proceedings of the Second International Symposium on Urban Stormwater Management 1995: Integrated Management of Urban Environments, Melbourne, Australia, 11-13 July 1995; Institution of Engineers, Australia: Barton, Australia, 1995; pp. 107-112.

38. Hardy, M.J.; Kuczera, G.; Coombes, P.J. Integrated urban water cycle management: The urbancycle model. Water Sci. Technol. 2005, 52, 1-9. [PubMed]

39. Mitchell, V.G.; Diaper, C.; Gray, S.R.; Rahilly, M.; Technolgy, C.M.A.I. Uvq: Modelling the movement of water and contaminants through the total urban water cycle. In Proceedings of the 28th International Hydrology and Water Resources Symposium, Wollongong, Australia, 10-13 November 2003; p. 8.

40. Clarke, L.; Lurz, J.; Wise, M.; Edmonds, J.; Kim, S.; Smith, S.; Pitcher, H. Model Documentation for the Minicam Climate Change Science Program Stabilization Scenarios: Ccsp Product 2.1 A; Pacific Northwest National Laboratory: Richland, WA, USA, 2007.

41. Snowdon, D.; Hardy, M.J.; Rahman, J.M. Urban developer: A model architecture for manageably building urban water cycle models spanning multiple scales. In Proceedings of the 19th International Congress on Modelling and Simulation, Perth, Australia, 12-16 December 2011.

42. Mitchell, V.G.; Diaper, C. Simulating the urban water and contaminant cycle. Environ. Model. Softw. 2006, 21, 129-134. [CrossRef]

43. Lai, E.; Lundie, S.; Ashbolt, N.J. Review of multi-criteria decision aid for integrated sustainability assessment of urban water systems. Urban Water J. 2008, 5, 315-327. [CrossRef]

44. Hajkowicz, S.; Collins, K. A review of multiple criteria analysis for water resource planning and management. Water Resour. Manag. 2007, 21, 1553-1566. [CrossRef]

45. Mutikanga, H.E.; Sharma, S.K.; Vairavamoorthy, K. Multi-criteria decision analysis: A strategic planning tool for water loss management. Water Resour. Manag. 2011, 25, 3947-3969. [CrossRef]

46. Moglia, M.; Kinsman, D.; Maheepala, S. Multi-Criteria Decision Assessment Methods to Identify Total Water Cycle Management Strategies; Urban Water Security Research Alliance: Queensland, Australia, 2012; Techincal Report No. 101.

47. Moglia, M.; Sharma, A.K.; Maheepala, S. Multi-criteria decision assessments using subjective logic: Methodology and the case of urban water strategies. J. Hydrol. 2012, 452-453, 180-189. [CrossRef]

48. Pomerol, J.-C.; Barba-Romero, S. Multicriterion Decision in Management: Principles and Practice; Springer Science \& Business Media: New York, NY, USA, 2000; Volume 25.

49. Brans, J.P.; Mareschal, B. The promcalc \& gaia decision support system for multicriteria decision aid. Decis. Support Syst. 1994, 12, 297-310.

50. Brans, J.P.; Mareschal, B. Promethee methods. In Multiple Criteria Decision Analysis: State of the Art Surveys; Figueira, J., Greco, S., Eds.; Springer Science + Business Media, Inc.: New York, NY, USA, 2005; pp. 163-195.

51. Kodikara, P.N.; Perera, B.J.C.; Kularathna, M.D.U.P. Stakeholder preference elicitation and modelling in multi-criteria decision analysis-A case study on urban water supply. Eur. J. Oper. Res. 2010, 206, 209-220. [CrossRef]

52. De Smet, Y.; Lidouh, K. An introduction to multicriteria decision aid: The promethee and gaia methods. In Business Intelligence; Aufaure, M.-A., Zimányi, E., Eds.; Springer: Berlin/Heidelberg, Germany, 2013; pp. 150-176.

53. Hayez, Q.; de Smet, Y.; Bonney, J. D-Sight: A new decision making software to address multi-criteria problems. Int. J. Decis. Support Syst. Technol. 2012, 4, 1-23. [CrossRef] 
54. Wong, T.H.F.; Brown, R.R. The water sensitive city: Principles for practice. Water Sci. Technol. 2009, 60, 673-682. [CrossRef] [PubMed]

55. Xue, X.; Schoen, M.E.; Ma, X.C.; Hawkins, T.R.; Ashbolt, N.J.; Cashdollar, J.; Garland, J. Critical insights for a sustainability framework to address integrated community water services: Technical metrics and approaches. Water Res. 2015, 77, 155-169. [CrossRef] [PubMed]

56. VicUrban. Aurora Development Part 2; Victoria Growth Area Authority: Whittlesea, Australia, 2007; p. 87.

57. Department of Transport, Planning and Local Infrastructure. Victoria in Future 2014 (VIF 2014); Department of Transport, Planning and Local Infrastructure: Melbourne, Australia, 2014.

58. Sharma, A.; Grant, A.; Gray, S.; Mitchell, G. Sustainability of Alternative Water and Sewerage Servicing Options-YVW; Kalkallo and Box Hill Pac Developments; CSIRO Urban Water: Highett, Australia, 2005.

59. ABS. Environmental Issues: Water Use and Conservation; Australian Bureau of Statistics: Canberra, Australia, 2010.

60. Sharma, A.; Tjandraatmadja, G.; Grant, A.; Grant, T.; Pamminger, F. Sustainable sewerage servicing options for peri-urban areas with failing septic systems. Water Sci. Technol. 2010, 62, 570-585. [CrossRef] [PubMed]

61. Metcalf and Eddy Inc.; Tchobanoglous, G.; Burton, F.L.; Stensel, H.D. Wastewater Engineering: Treatment and Reuse, 4th ed.; McGraw-Hill: New York, NY, USA, 2003.

62. FAO. Wastewater Treatment and Use in Agriculture; Food and Agriculture Organization of the United Nations: Rome, Italy, 1992.

63. Henze, M.; Comeau, Y. Wastewater characterization. In Biological Wastewater Treatment: Principles, Modelling and Design; Henze, M., van Loosdrecht, M.C.M., Ekama, G.A., Brdjanov, D., Eds.; IWA Publishing: London, UK, 2008; pp. 33-52.

64. Riahi, K.; Grübler, A.; Nakicenovic, N. Scenarios of long-term socio-economic and environmental development under climate stabilization. Technol. Forecast. Soc. Chang. 2007, 74, 887-935. [CrossRef]

65. Meinshausen, M.; Smith, S.; Calvin, J.K.; Daniel, J.S.; Kainuma, M.L.T.; Lamarque, J.F.; Matsumoto, K.; Montzka, S.A.; Raper, S.C.B.; Riahi, K.; et al. The rcp greenhouse gas concentrations and their extensions from 1765 to 2300. Clim. Chang. 2011, 109, 213-241. [CrossRef]

66. Mein, R.G.; Apostolidis, N. A simple hydrologic model for sewer inflow/infiltration. In Proceedings of the International Symposium on Urban Stormwater Management, Sydney, Australia, 4-7 February 1992; Barton, A., Ed.; Engineers Australia: Sydney, Australia; pp. 204-208.

67. Mankad, A.; Tapsuwan, S. Review of socio-economic drivers of community acceptance and adoption of decentralised water systems. J. Environ. Manag. 2011, 92, 380-391. [CrossRef] [PubMed]

68. EPA Victoria. Guidelines for Environmental Management: Use of Reclaimed Water; EPA Victoria: Victoria, Australia, 2003.

(C) 2015 by the authors; licensee MDPI, Basel, Switzerland. This article is an open access article distributed under the terms and conditions of the Creative Commons by Attribution (CC-BY) license (http://creativecommons.org/licenses/by/4.0/). 